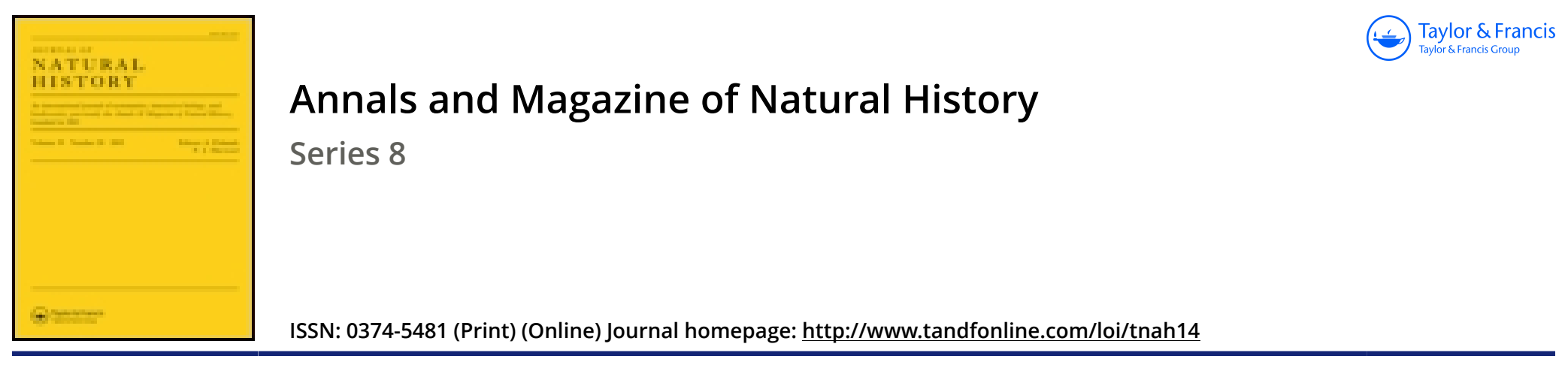

\title{
LX.-New non-marine Mollusca from Peru and Argentina
}

\section{H.B. Preston F.Z.S.}

To cite this article: H.B. Preston F.Z.S. (1914) LX.-New non-marine Mollusca from Peru and Argentina , Annals and Magazine of Natural History, 13:77, 522-528, DOI: 10.1080/00222931408693519

To link to this article: http://dx.doi.org/10.1080/00222931408693519

$$
\text { 电 Published online: } 15 \text { Sep } 2009 .
$$

Submit your article to this journal $\widetilde{ }$

Џ Article views: 2

Q View related articles $₫$

4 Citing articles: 2 View citing articles 진 
rugose, with a thick shining rim; under the microscope the sides of the area show strong ridges, which are vertical, not oblique; lateral margins of posterior truncation not sharply defined; tegulæ fulvous or rufo-fulvous. Wings clear, stigma and nervures ferruginous; outer nervures scarcely weakened; second s.m. broad below; first r. n. meeting second t.-c., or entering extreme apical corner of second s.m. Legs black, the knees and apices of tibiæ more or less pale reddish; tarsi cream-colour, becoming pale ferruginous apically. Abdomen broad, shining, first two segments tinely, not densely punctured; hind margins of segments very faintly, variably, reddish; bases of second and following segments with bands of pale tomentum, not always exposed; apical plate very broad, dark.

$H a b$. New South Wales, two specimens (Nat. Mus. Victoria, 102). Closely allied to H. clelandi, Ckll., but mesothorax and tarsi different.

\section{LX.-New Non-Marine Mollusca from Peru and Argentina. By H. B. Preston, F.Z.S.}

Ammonoceras pebasensis, sp. $\mathrm{n}$.

Shell small, depressedly conoid, with somewhat tumid last whorl and base, greenish yellow, polished, a little shining; whorls 5, regularly increasing, the apical whorls smooth, the remainder sculptured with fine, closely-set, somewhat wavy, spiral striæ crossed by transverse growth-plication; suture deeply impressed, indistinctly margined below; umbilicus moderately broad, deep, well-like, occupying about one-fifth of the total diameter of the shell ; columella margin descending somewhat obliquely, diffused above into a well-defined, restricted, parietal callus which reaches to the upper margin of the labrum; labrum acute, aperture ovate.

Alt. 3, diam. maj. 5, diam. min. $4.5 \mathrm{~mm}$.

Aperture : alt. $2 \cdot 25$, diam. $1.75 \mathrm{~mm}$.

Hab. Forests about Pebas, Rio Marañon, N.E. Peru.

Ammonoceras pucayaënsis, sp. n.

Shell small, orbicular, very depressed, semitransparent, vitreous, tinged with yellowish cream-colour and painted 
with multitudinous, narrow, spiral bands of the same; whorls 5, some what flattened, regularly increasing, sculptured with radiate, transverse stria and extremely fine and closelyset, rather wavy, microscopic, spiral striæ; suture impressed ; base of shell not very convex, sculptured as on the spire; umbilicus wide; columella margin obliquely descending; curved below, diffused above into a restricted, well-defined, whitish, parietal callus which reaches to the upper margin of the labrum ; labrum simple acute, receding below, a little projecting in front; aperture broadly and rather compressedly and obliquely sublunate.

Alt. $3 \cdot 25$, diam. maj. $7 \cdot 25$, diam. min. $6 \cdot 25 \mathrm{~mm}$.

Aperture: alt. $2 \cdot 5$, diam. $2 \cdot 25 \mathrm{~mm}$.

Hab. Rio Pucaya, Eastern Peru, at an altitude of 250 feet.

Ammonoceras rosenbergiana, sp. $\mathrm{n}$.

Shell allied to $A$. pucayaënsis, Preston, but of a pale yellowish-olive tint, with no trace of spiral colour-bands, the spire is rather more exserted, and, while the spiral striæ are even finer, the transverse striæ are much more pronounced; the suture is narrowly margined below, which is not the case in $A$. pucayaënsis, the last whorl descends somewhat, the umbilicus is much narrower, and the parietal callus is of a reddish hue.

Alt. $3 \cdot 5$ (nearly), diam. maj. 7 , diam. min. $6.25 \mathrm{~mm}$.

Aperture : alt. $2 \cdot 75$, diam. $2 \cdot 25$ (nearly) $\mathbf{m m}$.

Hab. Rio Pucaya, Eastern Peru.

\section{Bulimulus apicepunctata, sp. $\mathbf{n}$.}

Shell fusiform, reddish brown, variegated with oblique, transverse, cream-coloured bands; whorls $6 \frac{1}{2}$, not very convex, regularly increasing, the last rather long, the first two and a half regularly spirally punctate, the remainder smooth, but for transverse growth-lines; suture impressed, narrowly margined below with white; base of shell shouldered round the umbilicus, umbilicus somewhat broad, deep; columella margin vertically descending in a slight curve, thin, broadly outwardly expanded, diffused above into a light, well-defined, parietal callus, which enters the shell just behind the upper margin of the labrum; labrum whitish, outwardly expanded at the base, a little bent inwards over the aperture above; aperture rather elongately ovate.

Alt. 17.5, diam. maj. 9, diam. min. $7 \mathrm{~mm}$.

Aperture : alt. $7 \cdot 75$, diam. $3 \cdot 75 \mathrm{~mm}$.

Hab. Santa Kita, E. Peru. 
Orthalicus sultana angustior, sp. $\mathrm{n}$.

Shell differing from typical Helix sullana, Dillwyn *, in its more exserted spire and much narrower form.

Alt. 65, diam. maj. 40, diam. min. $33 \mathrm{~mm}$.

A perture: alt. 41 , diam. $23.5 \mathrm{~mm}$.

Hab. Eastern Peru.

\section{Opeas contamanoërtsis, sp. $\mathrm{n}$.}

Shell obtusely subulate, polished, shining, greyish green ; whorls $8 \frac{1}{4}$, the first two and a quarter submamillary, the remainder slowly and regularly increasing, somewhat convex, marked with slightly obliqne, transverse striæ; suture well impressed, irregularly crenellated and narrowly margined below; columella margin very slightly curved, obliquely truncate below, labrum simple acute; aperture broadly and rather shortly inversely auriform.

Alt. 15, diam. maj. $3 \cdot 75$, diam. min. $3.5 \mathrm{~mm}$.

A perture : alt. 3 , diam. $1.5 \mathrm{~mm}$.

Hab. Contamano, Rio Ucayali, Eastern Peru.

After examination of a long series of Opers octona, Ein., from many localities, I have been unable to altogether reconcile the above species with any of them, though it is undoubtedly closely allied to that form.

\section{Helicina basifilaris, sp. $\mathrm{n}$.}

Shell rather depressedly conic, slightly polished, brownish yellow, painted with a broad band of pale reddish on the lower half of the whorls, and showing to flesh-colour on the base of the shell; whorls $3 \frac{1}{2}$, the last acutely carinate at the periphery, closely and lightly, spirally lirate; suture impressed, very narrowly margined above; base of shell sculptured with very closely-set, somewhat wary, radiate, microscopic striæ, crossed by very fine, wavy, revolving striæ and marked with fine, somewhat distant, dark, revolving colour-lines; columella margin obliquely descending above, excavated below, thickened into an almost nodulous projection at the base, whitish, outwardly and upwardly extending into a granular, parietal callus; labrum bright yellow, receding below, narrowly outwardly expanded and reflexed, the outward expansion considerably diminishing above;

- Descriptive Cat. ii. 1817 , p. 920. 
aperture roughly subtriangular; operculum harp-shaped, concave, horny, laminiferous, granular, very dark chestnut shading to a paler hue towards the laterally placed nucleus.

Alt. $4 \cdot 5$, diam. maj. $7 \cdot 5$, diam. min. $6 \mathrm{~mm}$.

Aperture : alt. 3, diam. $3.25 \mathrm{~mm}$.

Hab. Rio Pucaya, Eastern Peru.

\section{Helicina contamanoënsis, sp. $n$.}

Shell broadly conoid, polished, shining, dark yellowish flesh-colour ; whorls 5, not very convex, regularly increasing, the last acutely carinate, gradually descending in front, marked with arcuate growth-lines and sculptured with very fine, confused, oblique striæ and distant spiral ridges; suture lightly impressed, narrowly, callously margined below; columella white, descending obliquely, and developed into an outwardly directed, nodular projection at the base, outwardly, callously diffused above into a thin, well-defined, granular, parietal callus ; labrum white, narrowly expanded and reflexed especially below, coarsely granular, receding towards the base, outwardly extended above; aperture broadly sagittiform ; operculum corneous, slightly concave, somewhat granular, laminiferous, with lateral nuclous, reddishchestnut shading to dark yellow towards the nucleus.

Alt. 9, diam. maj. 15, diam. min. $12.5 \mathrm{~mm}$.

A perture : alt. 5 , diam. $6.5 \mathrm{~mm}$.

Hab. Contamano, Rio Ucayali, Eastern Peru.

Allied to $H$. rhyncostoma (Shuttl.), Pfr. *, but with narrower and higher aperture; moreover, the spire is not laterally concave as in that species.

\section{Helicina inca, sp. $\mathrm{n}$.}

Shell allied to H.contamanoënsis, Preston, but differing from that species in its more depressedly conoid form and greenishyellow colour, and in being painted with a narrow, reddish, subcarinal band; the last whorl does not descend so much in front, and the distant spiral ridges of $H$. contamanoënsis give place to rather closely-set, impressed, spiral lines, while the base of the shell is sculptured with fine, closely-set, revolving strix; the columella is more excavated and is quite rounded, lacking the nodular projection at the base; the aperture is rather less broadly sagittiform and the labrum is rather less outwardly expanded than is the case in that species.

* Shuttleworth in Pfeiffer, Mon. Pneum. iii. 1865, p. 245. 
Alt. 8.5, diam. maj. 16, diam. min. $13 \mathrm{~mm}$. Aperture : alt. 6, diam. $6.5 \mathrm{~mm}$. $H a b$. Eastern Peru.

\section{Helicina lacerata, sp. n.}

Shell turbinately conic, bright yellow; whorls $4 \frac{1}{2}$, slightly inflated, regularly increasing, the last acutely carinate at the periphery, sculptured with moderately closely-set spiral liræ, very obliquely crossed by minute, confused, scratch-like striæ; suture lightly impressed, very narrowly callously margined above; base of shell sculptured with irregular, fine, wavy, revolving liræ, considerably confused by the oblique scratch-like striæ which are also present on this portion of the shell; columella margin whitish, descending in a gentle curve, thickened at the base into a slight nodular concretion, spreading outwards and upwards into a thin, ill-defined, granular parietal callus ; labrum yellow, outwardly expanded, reflexed, and receding below, projecting above, where it ceases to be reflexed ; aperture obliquely subrectangular, rounded at the base ; operculum horny, dark chestnut, shading to pale red in the median and nucleal regions, yellowish towards the base on the inner margin, slightly concave, granular, laminiferous, with lateral nucleus.

Alt. 6, diam. maj. 8, diam. min. $7 \mathrm{~mm}$.

Aperture: alt. $3 \cdot 75$, diam. $3 \cdot 75 \mathrm{~mm}$.

Hab. Rio Pucaya, Eastern Peru, at an altitude of 250 feet.

\section{Helicina syngenes, sp. $\mathrm{n}$.}

Shell allied to $I I$. lacerata, Preston, but rather more broadly conic in shape and lacking the inflation of the whorls; it is also of a pale flesh-colour; the liræ on the spire and base of $H$. lacerata give place in the present species to coarse, closely-set, spiral striæ, while the basal columellar nodule is wanting.

Alt. 6, diam. maj. 9, diam. min. $7 \cdot 5$ (nearly) mm.

Aperture : alt. $3 \cdot 75$, diam. $3.75 \mathrm{~mm}$.

Hab. Rio Pucaya, Eastern Peru, at an altitude of 250 feet.

\section{Helicina pucayaënsis, sp. n.}

Shell globosely turbinate, greenish grey, covered with a thin, hispid, light brownish periostracum; whorls $4 \frac{1}{2}$, the upper whorls flattened, the last inflated, the embryonic whorl 
sculptured with spiral punctate lines, the remaining whorls with very fine and oblique, confused, scratch-like striæ; suture very lightly impressed, very narrowly margined below, the margin being of a whitish colour; columella margin very obliquely descending, curved below, spreading outwards into a callous thickening and diffused upwards into an ill-defined, granular, parietal callus; labrum narrowly outwardly expanded and reflexed, pale flesh-coloured, notched at its junction with the columella; aperture obliquely and very broadly semilunate; operculum concave, transparent, calcareous, pale flesh-coloured, laminiferous, granular, with subcentral nucleus.

Alt. $6 \cdot 25$, diam. maj. $7 \cdot 5$, diam. min. $6 \mathrm{~mm}$.

A perture: alt. $3 \cdot 75$, diam. $3.25 \mathrm{~mm}$.

Hab. Rio Pucaya, Eastern Peru, at an altitude of 250 feet.

\section{Helicina serina, sp. $\mathrm{n}$.}

Shell conically turbinate, bright yellow, painted with a narrow cream-coloured peripheral band, and shading to the same colour in places on the base; whorls 5 , regularly increasing, the last angled at the periphery, the embryonic whorls minutely pitted, the remainder marked with transverse growth-lines, crossed in all directions by oblique scratch-like striæ; suture impressed, very narrowly margined with white below ; base of shell moderately convex, showing the scratchlike striæ of the spire, densely radiately striate; columella margin descending in a short and very gentle curve, outwardly callously thickened, and diffused upwards into, an illdefined, coarsely granular, parietal callus; labrum narrowly ontwardly expanded and rellexed, of a granular texture, bearing a slight notch at the base of the columella, in colour a bright intense yellow; aperture rather oblique, broadly and depressedly sublunate; operculum horny, reddish-chestnut coloured, granular, a little convex, laminiferous, with lateral nucleus.

Alt. 9, diam. maj. 10, diam. min. $8.25 \mathrm{~mm}$.

Aperture: alt. $4 \cdot 25$, diam. $4 \cdot 75 \mathrm{~mm}$.

Hab. Contamano, Rio Ucayali, Eastern Peru.

Ampullaria contamanoënsis, sp. $\mathrm{n}$.

Shell roughly ovate, broadly umbilicate, ashen grey, shading to yellowish brown below, and painted with spiral 
chocolate bands of irregular width ; whorls $4 \frac{1}{4}$, almost planulate above, then shouldered and rounded below, the last descending considerably in front and rather elongated towards the base, smooth; suture impressed, painted bolow with a very broad, whitish-grey, spiral band; umbilicus funnelshaped, deep; columella margin acute, almost erect, descending in a curve; labrum acute, slightly dilated below; aperture elongately ovate; interior of shell livid greyish brown, shading to chocolate.

Alt. 52, diam. maj. 42.5, diam. min. $36 \mathrm{~mm}$.

Aperture : alt. 39 , diam. $22 \mathrm{~mm}$.

Hab. Contamano, Rio Ucayali, Eastern Peru.

\section{Corbicula bermejoensis, sp. $\mathrm{n}$.}

Shell subtrigonal, whitish cream-colour, almost smooth, marked only with very fine concentric striæ; dorsal margin arched; ventral margin gently curved; anterior side rounded; posterior side rather abruptly descending, angled below; right valve bearing a very oblique, marginal anterior and two short, solid, posterior cardinal teeth and two curved serrated laterals on either side; left valve bearing two solid and divergent anterior and a very oblique, slightly curved and elongated, well-developed posterior cardinal tooth, and a coarsely serrated curved lateral on either side.

Long. 9, lat. $9 \cdot 25 \mathrm{~mm}$.

Hab. Rio Bermejo, a tributary of the Rio Chaco, N. Argentina (Clark).

\section{Corbicula approximans, sp. $\mathrm{n}$.}

Shell differing from C. bermejoensis, Preston, in its much more ovate form, it being much more laterally produced on either side, but especially anteriorly, than in that species; it is also much more coarsely concentrically striate, and the cardinal teeth are weaker, chiefly in the right valve.

Long. 10 (nearly), lat. 11 (nearly) $\mathrm{mm}$.

Hab. Rio Bermejo, a tributary of the Chaco, N. Argentina (Clark). 